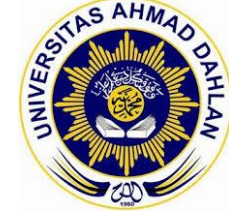

BERKALA FISIKA INDONESIA

Jurnal IImiah Fisika, Pembelajaran dan Aplikasinya

http://journal.uad.ac.id/index.php/BFl/index 2085-0409 (Print) | 2550-0465 (online)

\title{
Pembelajaran online dengan google classroom pada materi gerak lurus di sekolah menengah
}

\author{
Abd Rohman ${ }^{1 *}$, Dwi Sulisworo ${ }^{2}$ \\ 1,2 Megister Pendidikan Fisika, Fakultas Keguruan dan Ilmu Pendidikan, Universitas Ahmad Dahlan, Indonesia \\ Email: abdrohmanfauzy5@gmail.com* \\ * Penulis korespondensi
}

\begin{tabular}{l}
\hline Informasi artikel \\
\hline Sejarah artikel: \\
Dikirim \\
Revisi \\
Diterima \\
\hline
\end{tabular}

\section{Kata kunci:}

Google classroom

Learning management system

Media pembelajaran

Pengembangan media

\section{Keywords:}

Google classroom Learning management system

Instructional media

Media development

\begin{abstract}
ABSTRAK
Penelitian ini bertujuan mengembangkan pembelajaran berbasis Learning Management System pada materi Gerak Lurus. Metode penelitian yang digunakan adalah Research and Development (R\&D). Siswa kelas X SMA Arrohmaniyah Ombul telah dilibatkan sebagai subyek dalam penelitian ini. Data dikumpulkan melalui lembar validasi ahli dan angket respon. Hasil penelitian menunjukkan bahwa google classroom sebagai Learning Management System pada materi Gerak Lurus layak digunakan. Persentase rata-rata validasi ahli sebesar $78,8 \%$, kategori valid. Hasil respon guru fisika rata-rata sebesar $82 \%$, kategori sangat tertarik. Respon siswa yang setuju dan sangat setuju pada uji coba kelompok kecil dan kelompok besar masing-masing sebesar $76 \%$ dan $92 \%$. Jadi, dapat simpulkan bahwa media pembelajaran Google classroom layak digunakan.
\end{abstract}

This is an open access article under the CC-BY-SA license

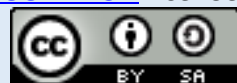

\section{ABSTRACT}

Online learning with google classroom on straight motion material in secondary schools. This study aims to develop a Learning Management System based on learning on straight motion material. The research method used is Research and Development (R\&D). Class X students of SMA Arrohmaniyah Ombul have been involved as subjects in this study. Data were collected through expert validation sheets and response questionnaires. The results showed that google classroom as a Learning Management System on Straight Motion material is feasible to use. The average percentage of expert validation is $78.8 \%$, the category is valid. The results of the physics teacher response on average were $82 \%$, a very interesting category. Students who agree and strongly agree in small group and large group trials are $76 \%$ and $92 \%$, respectively. So, it can be concluded that Google classroom learning media is feasible to use.

\section{How to Cite:}

Rohman, A., \& Sulisworo, D. (2020). Pembelajaran online dengan google classroom pada materi gerak lurus di sekolah menengah. Berkala Fisika Indonesia: Jurnal Ilmiah Fisika, Pembelajaran dan Aplikasinya, 11(1), 32-39. 


\section{Pendahuluan}

Dewasa ini, telah terjadi akselerasi integrasi teknologi dalam bidang Pendidikan, termasuk bidang Pendidikan fisika (Fayanto et al., 2019; Susilawati et al., 2019). Integrasi teknologi dalam Pendidikan fisika tidak hanya memberikan berbagai kemudahan bagi siswa dan guru saja. Namun, orang tua siswa juga mendapatkan berbagai kemudahan dalam mengontrol aktivitas belajar anaknya. Kemajuan global dalam teknologi informasi dan komunikasi telah mengakibatkan terjadinya pergeseran pembelajaran berbasis jaringan, yang berdampak besar pada pembelajaran berbasis internet (Arquero et al., 2017). Berbagai produk pengajaran berbasis teknologi telah dikembangkan pada bidang Pendidikan fisika, seperti pembelajaran berbasis web (Misalnya: Asyhari \& Diani, 2017; Kurniawan, 2017; Solihudin JH, 2018) dan pembelajaran berbasis smartphone (Misalnya: Hudan Ramadhan et al., 2019; Khansa \& Sulisworo, 2016).

Google classroom adalah salah satu bentuk teknologi pembelajaran berbasis web yang banyak digunakan dewasa ini. Google classroom merupakan aplikasi gratis yang menyediakan berbagai fitur pembelajaran untuk menjembatani komunikasi Pendidikan antara guru dan siswa (Hariadi et al., 2019).. Sebagai bagian dari Learning Management System (LMS), guru diberi kebebasan dalam membuat dan mengatur kelas, menambah bahan ajar, menambah siswa, menambah pengumuman, tugas, topik diskusi, dan komentar. Selain itu, guru dapat menggunakan kembali postingan lama, komunikasi, melampirkan file, video Youtube, link website, maupun Google Drive. Berbgai fitur dan kemudahan yang ditawarkan oleh google classroom dapat dijadikan dasar pertimbangan untuk mengembangkan lingkungan belajar yang efekstif dan efisien. Oleh karena itu, perlu mengembangkan pembelajaran berbasis Learning Management System (LMS) pada Pendidikan fisika. Pengembangan ini diharapkan menjadikan pembelajaran lebih bermakna bagi guru dan siswa.

Wawancara dengan guru fisika kelas X SMA Arrohmaniyah mengungkapkan bahwa guru tersebut belum pernah menggunakan Learning Management System (LMS) untuk memfasilitasi pembelajaran. Guru hanya menggunakan buku teks sekolah, powerpoint, dan bahan tertulis lainnya untuk mengajar. Sekolah mempunyai fasilitas wifi serta lab yang mencukupi untuk dikembangkan Learning Management System. Hingga pada pengambangan ini peneliti berharap media pembelajaran Learning Management System pada modul gerak lurus dapat membantu guru serta siswa untuk menanggulangi proses Pembelajaran berbasis Tatap Muka (PTM), membuat siswa lebih tertarik untuk belajar serta membuat siswa lebih leluas dalam mengakses materi gerak lurus. Berdasarkan latar belakang yang telah dijelaskan, maka penelitian ini bertujuan untuk mengembangkan media pembelajaran dengan memanfaatkan google classroom sebagai Learning Management System pada materi gerak lurus di SMA Arrohmaniyah Ombul. 


\section{Metode}

Penelitian ini termasuk dalam jenis penelitian Research and Development (R\&D) (Sugiyono, 2015). Langkah pengembangan media pembelajaran Learning Management System mengadopsi yang disarankan oleh Beniston, Ellwood, Gold, Roberts, \& Thorpe (2014). Langkah-langkah pengembangan yang diadopsi meliputi: 1. Menggali potensi dan masalah, 2. Mengumpulkan data, 3. Mendesain media, 4. Validasi desain, 5. Revisi desain, 6. Uji coba media, 7. Media pembelajaran Leaning Managemen System. Subyek dalam penelitian ini adalah siswa kelas X SMA Arrohmaniyah Ombul, Sampang, Madura. Uji skala kecil dilakukan terhadap 5 siswa dan uji coba skala besar dilakukan pada 10 siswa.

Instrumen yang digunakan dalam penelitian meliputi lembar validasi ahli materi dan media, angket respon guru dan respon siswa. Hasil penilaian kelayakan ahli dikelompokkan ke dalam empat tingkat, yaitu: tidak layak digunakan, layak dengan revisi mayor, layak dengan revisi minor dan layak digunakan tanpa revisi. Sedangkan skala penialaian dalam angket respon guru dan siswa menggunakan skala likert 5 poin, mulai dari 1 (sangat tidak setuju) sampai 5 (sangat setuju) (Arikunto \& Jabar, 2010). Data dianalisis dengan teknik persentase.

\section{Hasil dan Pembahasan}

\section{Validasi Produk}

Validasi telah dilakukan oleh ahli materi dan media. Hasil validasi ditabulasikan dalam Tabel 1.

Tabel 1. Data hasil validasi ahli materi dan media

\begin{tabular}{|c|c|c|c|c|}
\hline \multirow{2}{*}{ Komponen } & \multirow{2}{*}{ Indikator } & \multicolumn{2}{|c|}{ Validator } & \multirow[t]{2}{*}{ skor } \\
\hline & & 1 & 2 & \\
\hline \multirow[t]{14}{*}{ Aspek ahli materi } & Kesesuaian antara materi dan KD & 4 & 2 & 6 \\
\hline & Variasi penyajian materi & 3 & 3 & 6 \\
\hline & Ketepatan penerapan strategi belajar mandiri & 3 & 4 & 7 \\
\hline & Ketersediaan kamus yang relevan & 4 & 2 & 6 \\
\hline & Cakupan materi & 3 & 4 & 7 \\
\hline & Kejelasan isi materi & 3 & 4 & 7 \\
\hline & Runut isi materi & 3 & 2 & 5 \\
\hline & Struktur materi & 3 & 2 & 5 \\
\hline & Kejelasan bahasa yang digunakan & 4 & 4 & 8 \\
\hline & Kejelasan informasi pada ilustrasi gambar & 2 & 3 & 5 \\
\hline & Kemutakhiran data yang ditampilkan & 3 & 2 & 5 \\
\hline & Kesesuaian materi dengan kompetensi dasar & 3 & 4 & 7 \\
\hline & Total & & & 74 \\
\hline & Pesentase skor rata-rata & & & $77,10 \%$ \\
\hline \multirow{2}{*}{ Komponen } & \multirow{2}{*}{ Indikator } & \multicolumn{2}{|c|}{ Validator } & skor \\
\hline & & 1 & 2 & \\
\hline \multirow[t]{9}{*}{ Aspek ahli media } & Kemudahan dalam mencari alamat web & 3 & 3 & 6 \\
\hline & Kemudahan akses & 3 & 3 & 6 \\
\hline & Kemudahan login dan logout & 4 & 4 & 8 \\
\hline & Kemenarikan tampilan desain menu utama & 3 & 3 & 6 \\
\hline & Kecocokan warna tampilan menu utama & 3 & 3 & 6 \\
\hline & Kelengkapan pilihan menu utama & 4 & 4 & 8 \\
\hline & Proporsi layout bagian konten & 3 & 4 & 7 \\
\hline & Proporsi layout bagian materi & 4 & 3 & 7 \\
\hline & Kesesuaian warna & 3 & 3 & 6 \\
\hline
\end{tabular}


Tabel 2. Lanjutan Tabel 1

\begin{tabular}{|c|c|c|c|c|}
\hline \multirow{2}{*}{ Komponen } & \multirow{2}{*}{ Indikator } & \multicolumn{2}{|c|}{ Validator } & \multirow[t]{2}{*}{ skor } \\
\hline & & 1 & 2 & \\
\hline \multirow[t]{11}{*}{ Aspek ahli media } & Kesesuaian jenis font & 3 & 3 & 6 \\
\hline & Kemenarikan sajian animasi & 3 & 2 & 5 \\
\hline & Kesesuaian animasi dengan materi & 3 & 3 & 6 \\
\hline & Tampilan hanya mengandung objek yang relevan & 3 & 4 & 7 \\
\hline & Kemenarikan unsur media (gambar dan animasi) & 3 & 3 & 6 \\
\hline & Kemudahan pemakaian & 4 & 3 & 7 \\
\hline & Kemudahan navigasi & 3 & 4 & 7 \\
\hline & Kebebasan memilih menu Materi & 3 & 3 & 6 \\
\hline & Kemudahan berinteraksi dengan program Web LMS & 3 & 3 & 6 \\
\hline & Total & & & 115 \\
\hline & Pesentase skor rata-rata & & & $79,9 \%$ \\
\hline
\end{tabular}

Dari Tabel 1, hasil validasi ahli materi ini diperoleh skor sebesar 74 dengan persentase $77,1 \%$ (kategori valid). Pada item 9 tentang Kejelasan bahasa yang digunakan lebih tinggi nilainya dari pada item yang lain. Hal ini menunjukkan bahwa Learning Management System untuk penyajian materi gerak perlu lebih dioptimalkan. Gambar 1 menggambarkan tampilan konten google classroom.

Hasil validasi dari ahli media adalah 115 poin (79,9\%), kategori valid. Pernyataan 3 dan 6 mendapat skor yang lebih tinggi dalam hasil validasi karena kemudahan untuk login dan logout classroom. Opsi menu utama dan presentasi sama-sama menarik. Pernyataan lain menerima skor evaluasi yang lebih rendah. Hal ini menunjukkan bahwa Learning Management System juga perlu mengalami perubahan. Pilihan menu utama yang disediakan mudah dipahami oleh siswa. Gambar 2 menunjukkan contoh tampilan media. Secara keseluruhan, rerata hasil validasi oleh ahli media dan materi sebesar 78,8\% (kategori valid). Jadi, dapat disimpulkan bahwa Learning Management System valid digunakan untuk mengajarkan materi Gerak Lurus.

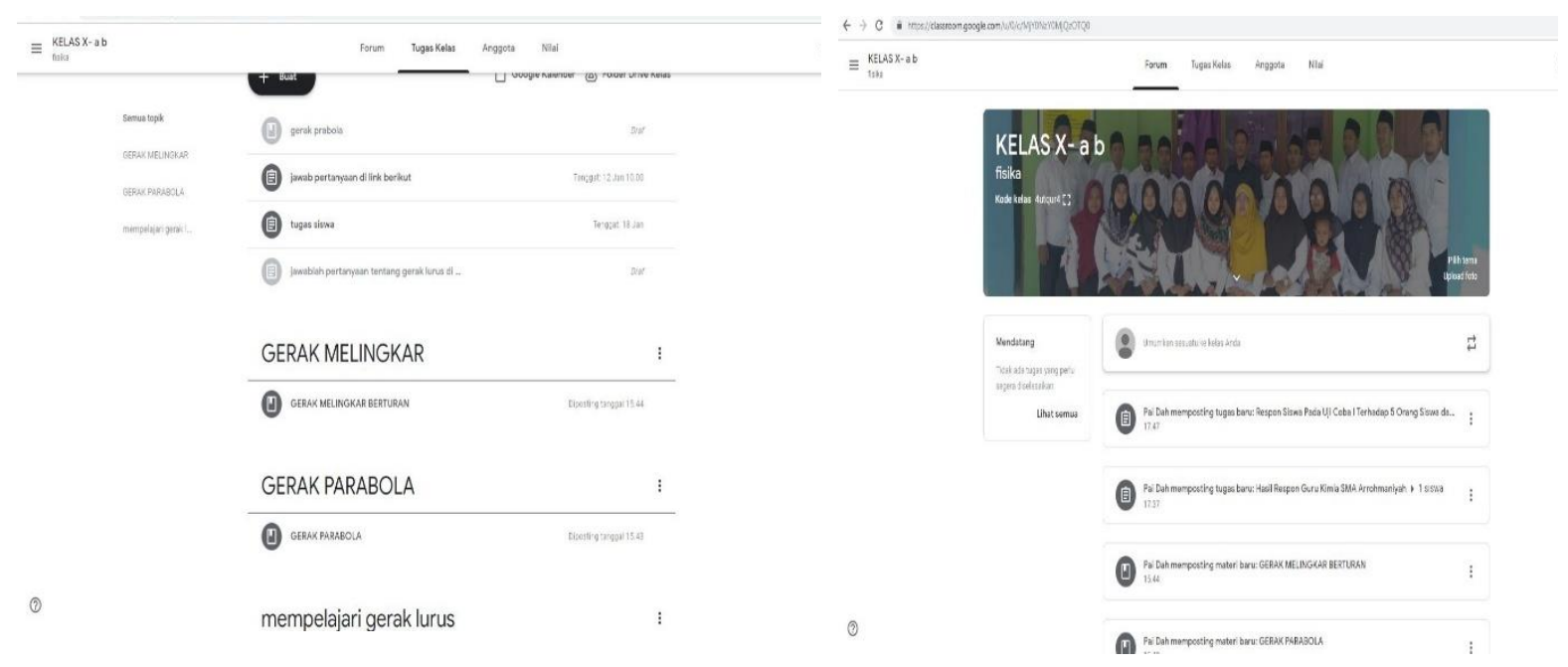

Gambar 1a. Materi fisika

Gambar 1b. Kelas X classroom 


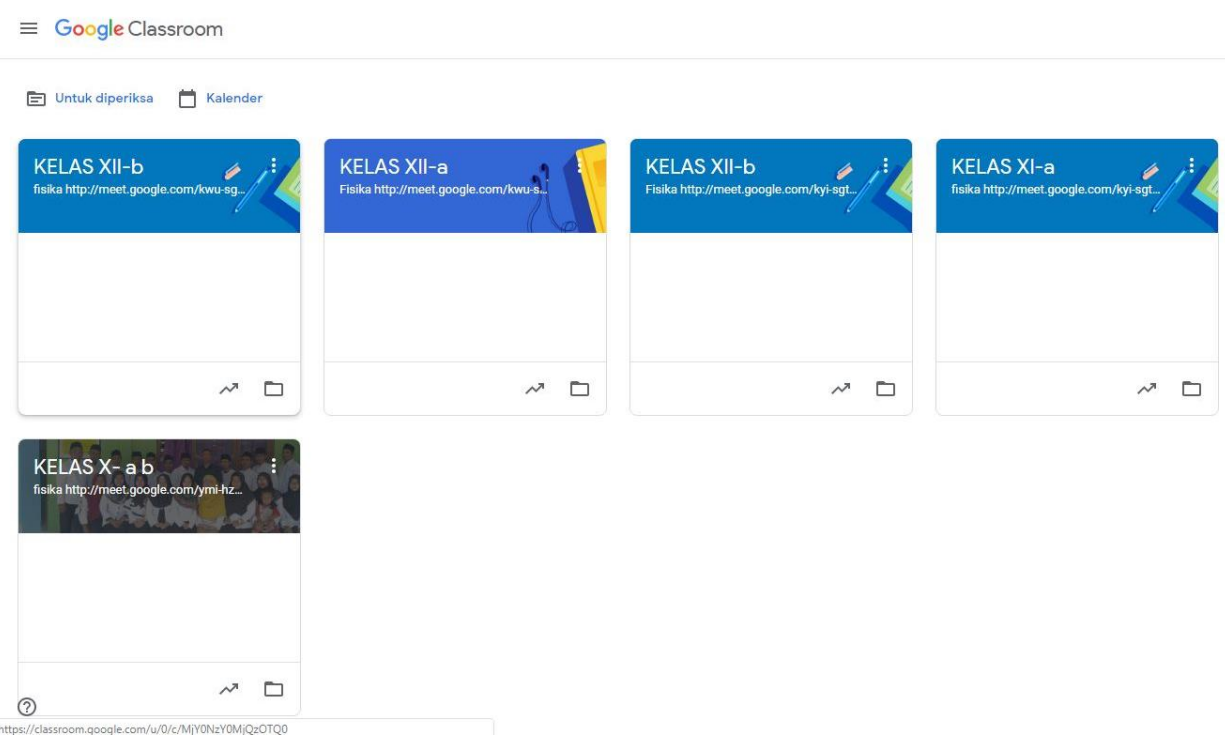

Gambar 2. Hasil media

Respon Guru

Setelah melakukan perubahan berdasarkan rekomendasi ahli, guru fisika di SMA Arrahmaniyah Ombul melakukan evaluasi. Tanggapan guru terhadap media pembelajaran Learning Management System pada materi gerak lurus ditampilkan dalam Tabel 2.

Tabel 3. Data hasil tanggapan guru SMA Arrohmaniyah

\begin{tabular}{lc}
\hline \multicolumn{1}{c}{ Pernyataan } & Skor \\
\hline Kemenarikan tampilan media pembelajaran. & 3 \\
Kemudahan penggunaan oleh guru. & 5 \\
Kemudahan penggunaan tombol Navigasi. & 3 \\
Kesesuaian antara materi dan KD. & 4 \\
Kemudahan membaca teks. & 4 \\
Penggunaan bahasa yang mudah dipahami. & 5 \\
Kelengkapan dan keakuratan penyajian materi. & 4 \\
Penggunaan media membantu menciptakan pembelajaran yang menyenangkan. & 5 \\
Penggunaan media memudahkan penyampaian informasi materi pembelajaran. & 3 \\
Kemudahan dalam mengunggah materi pembelajaran. & 5 \\
\hline Total & $\mathbf{4 1}$ \\
Pesentase skor rata-rata & $\mathbf{8 2 \%}$ \\
\hline
\end{tabular}

Berdasarkan Tabel 2, diperoleh persentase respon guru terhadap media yang dikembangkan sebesar $82 \%$. Nilai ini termasuk dalam kategori sangat menarik. Tanggapan guru menunjukkan bahwa media yang dikembangkan mudah digunakan, bahasa yang digunakan mudah dipahami, dan mampu menciptakan pembelajaran yang menyenangkan. Unsur kemenarikan tampilan, kemudahan penggunaan tombol navigasi, dan kemudahan penggunaan media dalam penyampaian materi pembelajaran perlu menjadi perhatian khusus karena mendapat poin 3.

\section{Respon Siswa}

Setelah menerima hasil respon guru, dilakukan uji coba pada siswa. Pengujian produk bertujuan untuk mengetahui bagaimana siswa menanggapi Learning Management System yang dibangun. 
Pengujian produk dilakukan dalam dua tahap yaitu pengujian kelompok kecil dan pengujian kelompok ekstensif. Respon siswa pada kedua uji coba ditampilkan dalam Tabel 3.

Tabel 4. Respon Siswa pada Tahap I dan II.

\begin{tabular}{|c|c|c|c|c|c|c|c|c|c|c|}
\hline \multirow[t]{2}{*}{ Pernyataan } & \multicolumn{5}{|c|}{ Kelompok kecil (Tahap I) } & \multicolumn{5}{|c|}{ Kelompok besar (Tahap II) } \\
\hline & SS & $\mathbf{S}$ & KS & TS & STS & SS & $\mathbf{S}$ & KS & TS & STS \\
\hline $\begin{array}{l}\text { Kemenarikan tampilan media } \\
\text { pembelajaran. }\end{array}$ & 60 & 40 & 0 & 0 & 0 & 80 & 20 & 0 & 0 & 0 \\
\hline Kemudahan penggunaan oleh siswa. & 20 & 80 & 0 & 0 & 0 & 60 & 40 & 0 & 0 & 0 \\
\hline Kemudahan penggunaan tombol Navigasi. & 20 & 40 & 40 & 0 & 0 & 80 & 0 & 20 & 0 & 0 \\
\hline Kemudahan memahami materi. & 40 & 40 & 20 & 0 & 0 & 60 & 40 & 0 & 0 & 0 \\
\hline Kejelasan teks. & 60 & 40 & 0 & 0 & 0 & 80 & 20 & 0 & 0 & 0 \\
\hline Kemenarikan gambar dan animasi. & 0 & 20 & 60 & 20 & 0 & 80 & 0 & 20 & 0 & 0 \\
\hline Sajian materi mudah dipahami. & 20 & 60 & 20 & 0 & 0 & 60 & 40 & 0 & 0 & 0 \\
\hline $\begin{array}{l}\text { Penggunaan media membantu } \\
\text { menciptakan pembelajaran yang } \\
\text { menyenangkan. }\end{array}$ & 60 & 20 & 20 & 0 & 0 & 80 & 20 & 0 & 0 & 0 \\
\hline $\begin{array}{l}\text { Penggunaan media memudahkan akses } \\
\text { materi pembelajaran. }\end{array}$ & 40 & 40 & 20 & 0 & 0 & 60 & 20 & 20 & 0 & 0 \\
\hline $\begin{array}{l}\text { Penggunaan media meningkatkan } \\
\text { motivasi }\end{array}$ & 20 & 40 & 20 & 20 & 0 & 60 & 20 & 20 & 0 & 0 \\
\hline Jumlah & 340 & 420 & 200 & 40 & 0 & 700 & 220 & 80 & 0 & 0 \\
\hline Persentase & 34 & 42 & 20 & 4 & 0 & 70 & 22 & 8 & 0 & 0 \\
\hline
\end{tabular}

Ket: SS = sangat setuju, S = setuju, TS = Tidak Setuju, STS = Sangat Tidak Setuju

Berdasarkan Tabel 3, pada tahap I diketahui bahwa siswa yang menjawab sangat setuju (SS) 34\%, siswa yang menjawab setuju (S) 42\%, siswa yang menjawab kurang setuju (KS) $20 \%$. Sedangkan siswa yang menjawab tidak setuju (TS) $4 \%$ dan siswa yang menjawab sangat tidak setuju (STS) $0 \%$. Hasil uji coba tahap II diketahui bahwa siswa yang menjawab sangat setuju (SS) 70\%, siswa yang menjawab setuju (S) 22\%. Sedangkan siswa yang menjawab kurang setuju (KS) $8 \%$, siswa yang tidak setuju (TS) dan sangat tidak setuju (STS) masing-masing sebesar 0\%. Secara keseluruhan dapat disimpulkan bahwa siswa sangat setuju terhadap media pembelajaran Learning Management System materi Gerak Lurus.

Respon siswa tahap I dan II ditampilkan dalam Gambar 4 dan 5. Hasil penelitian ini relevan dengan penelitian yang dilakukan oleh Sudibyo (2013) dan Januarisman \& Ghufron (2016).

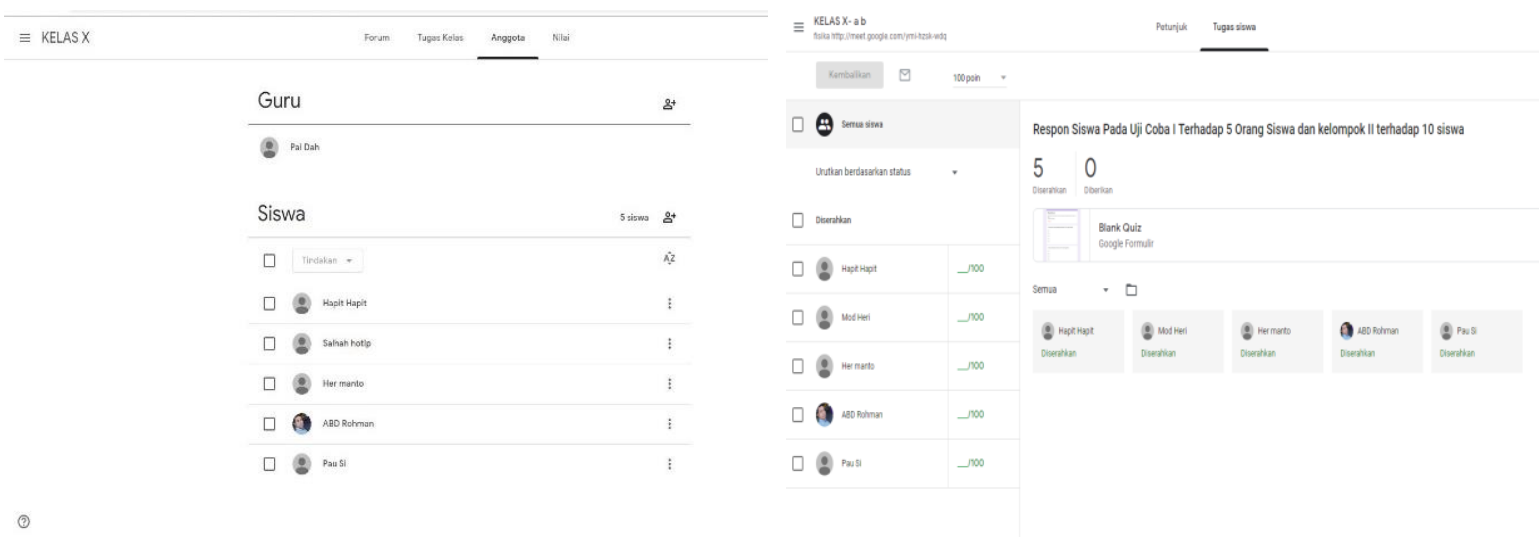

Gambar 4. Respon siswa tahap I 


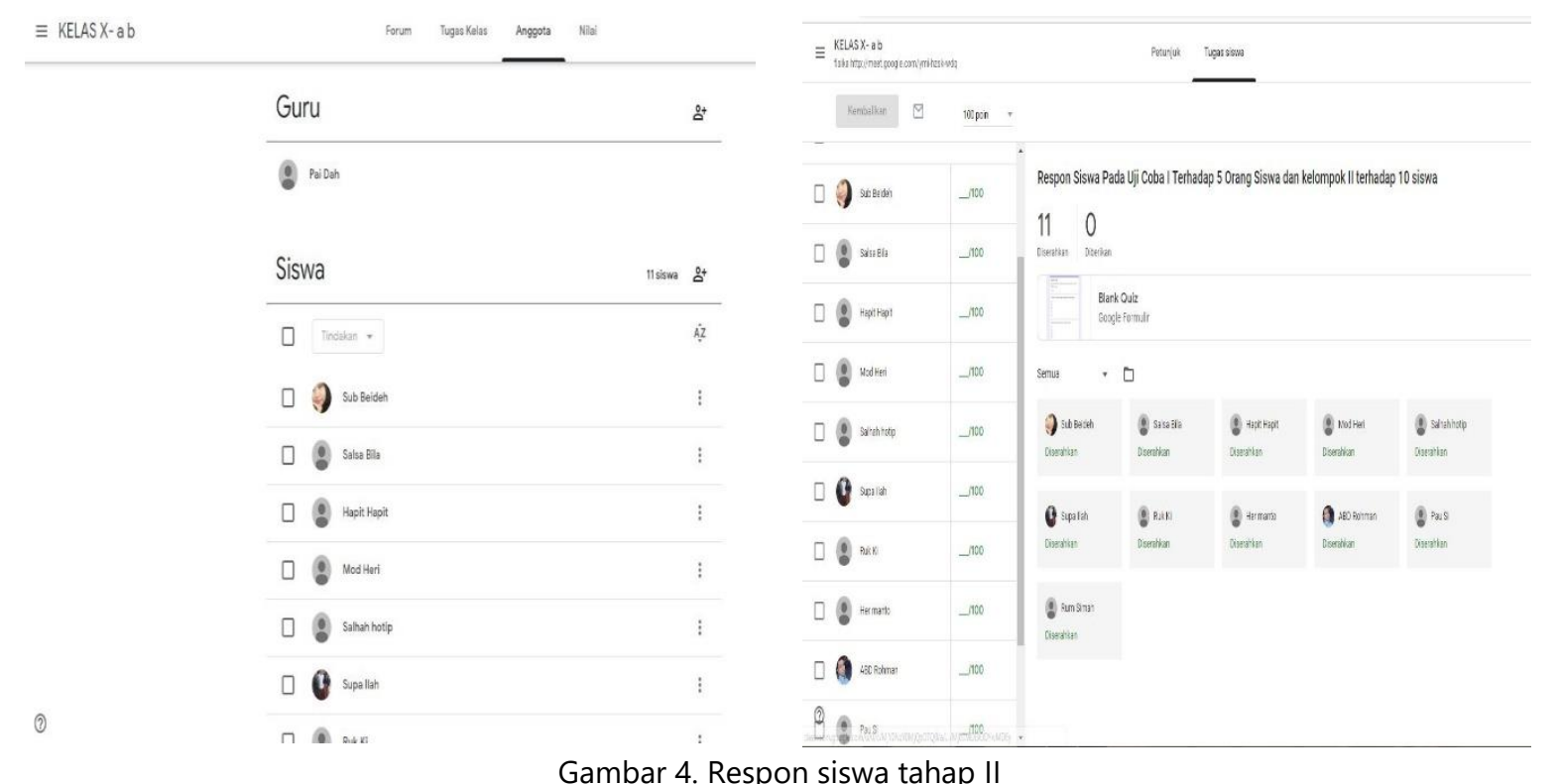

\section{Simpulan}

Berdasarkan hasil pengembangan media pembelajaran Learning Management System pada materi Gerak Lurus yang telah dilakukan dapat disimpulkan bahwa: (1). Validasi ahli media dan ahli materi menghasilkan masing-masing $79,9 \%$ dan $77,1 \%$. Total persentase $78,8 \%$ secara keseluruhan (kategori valid). (2). Respon guru fisika terhadap Learning Management System adalah 82\% (kategori sangat baik) untuk materi gerak lurus. (3). Siswa menanggapi Learning Management System dengan $34 \%$ sangat setuju (SS) dan $42 \%$ setuju (S) dalam uji coba kelompok kecil. Sedangkan uji coba kelompok besar $70 \%$ Sangat Setuju (SS), dan 22\% Setuju (S).

Hasil validasi media yang dikembangkan sudah layak digunakan dalam kegiatan belajar mengajar. Namun demikian, beberapa saran yang perlu disampaikan antara lain: (1). Pendidik diharapkan dapat menggunakan media pembelajaran Learning Management System sehingga mempermudah pelaksanaan pembelajaran, (2). Peserta didik diharapkan dapat melanjutkan pembelajaran seperti yang dilakukan, (3). Peneliti lain diharapkan dapat melanjutkan penelitian tentang implementasi Learning Management System untuk menigkatkan hasil belajar siswa.

\section{References}

Arikunto, S., \& Jabar, C. S. A. (2010). Evaluasi program pendidikan: Pedoman teoritis praktis bagi praktisi pendidikan. Jakarta: Bumi Aksara.

Arquero, J. L., del Barrio-García, S., \& Romero-Frías, E. (2017). What drives students' loyalty-formation in social media learning within a personal learning environment approach? The moderating role of need for cognition. Journal of Educational Computing Research, 55(4), 495-525.

Asyhari, A., \& Diani, R. (2017). Pembelajaran fisika berbasis web enhanced course: mengembangkan web-logs pembelajaran fisika dasar I. Jurnal Inovasi Teknologi Pendidikan, 4(1), 13-25.

Beniston, L., Ellwood, P., Gold, J., Roberts, J., \& Thorpe, R. (2014). Innovation development - an action learning programme for medical scientists and engineers. Action Learning: Research and Practice, 11(3), 311-329.

Fayanto, S., Kawuri, M. Y. R. T., Jufriansyah, A., Setiamukti, D. D., \& Sulisworo, D. (2019). Implementation e-learning based moodle on physics learning in senior high school. Indonesian Journal of Science and Education, 3(2), 93-102. 
Hariadi, M. H., Jumadi, J., Wilujeng, I., Kuswanto, H., Wulandari, W., \& Sundari, S. (2019). Inquiry training learning model assisted by google classroom to improve creative thinking skills of senior high school students. JPI (Jurnal Pendidikan Indonesia), 8(2), 198-207.

Hudan Ramadhan, R., Ratnaningtyas, L., Kuswanto, H., \& Wardani, R. (2019). Analysis of physics aspects of local wisdom: long bumbung (bamboo cannon) in media development for android-based physics comics in sound wave chapter. Journal of Physics: Conference Series, 1397, 012016.

Januarisman, E., \& Ghufron, A. (2016). Pengembangan e-learning berbasis moodle pembelajaran ilmu pengetahuan alam (IPA) bagi siswa kelas V SD Negeri Kotagede I. Jurnal Inovasi Teknologi Pendidikan, 3(2), 166-182.

Kaniawati, I. (2017). Pengaruh simulasi komputer terhadap peningkatan penguasaan konsep impuls-momentum siswa SMA. Jurnal Pembelajaran Sains, 1(1), 24-26.

Khansa, M. L., \& Sulisworo, D. (2016). Pengembangan media pembelajaran fisika berbasis android sebagai daya dukung pembelajaran siswa homeschooling. Prosiding Seminar Pendidikan Fisika, Fisika, dan Aplikasinya, 117-122.

Kurniawan, F. A. (2017). Pengaruh pembelajaran berbasis web terhadap motivasi dan hasil belajar siswa kelas X SMA Negeri Paguyangan pada mata pelajaran fisika pokok bahasan suhu dan kalor. Scientiae Educatia, 6(1), 1-7.

Lee, J.-H. (2000). Analysis of tire effect on the simulation of vehicle straight line motion. Vehicle System Dynamics, 33(6), 373-390.

Savahl, S., September, R., Odendaal, W., \& Moos, A. (2008). Information and Communication Technology: A Descriptive Study of Children's Communication Patterns. South African Journal of Psychology, 38(3), 515525.

Solihudin JH, T. (2018). Pengembangan e-modul berbasis web untuk meningkatkan pencapaian kompetensi pengetahuan fisika pada materi listrik statis dan dinamis SMA. WaPFi (Wahana Pendidikan Fisika), 3(2), 5161.

Sudibyo, A. (2013). Penggunaan media pembelajaran fisika dengan e-learning berbasis edmodo blog education pada materi alat optik untuk meningkatkan respons motivasi dan hasil belajar siswa di SMP Negeri 4 Surabaya. Inovasi Pendidikan Fisika, 2(3), 187-190.

Sugiyono. (2015). Metode penelitian kualitatif, kuntitatif dan R\&D. Bandung: Alfabeta.

Susilawati, S., Ishafit, I., \& Setyawati, E. (2019). Development student worksheet in the topic of regular circular motion with blended learning based edmodo as learning motivations for student. Indonesian Review of Physics, 2(2), 28-33. 